\title{
Internal Labour Market as Factor in the Career Success Perceived by an Engineer
}

\author{
Mercado Interno de Trabalho como Fator de Sucesso na Carreira \\ Percebido pelo Engenheiro \\ Mercado Interno de Trabajo como Factor de Éxito en la Carrera
Percibido por Ingeniero
}

Alberto Ismael Bejarano Heredia ${ }^{1}$

Kety Lourdes Jauregui Machuca²

Recebido em 22 de julho de 2010 / Aprovado em 10 de junho de 2011

Editor Responsável: João Maurício Gama Boaventura, Dr.

Processo de Avaliação: Double Blind Review

\begin{abstract}
The phenomenon of the global crisis in both the financial energy sectors as well as the emergence of new technologies companies consider their success or failure depending on the ability to respond quickly to opportunities in their competitive environment. This competitiveness is found especially in the capacity of their technical professionals. On the other hand career is characterized as protean, boundaryless and directed mainly by the individual. Given this scenario, organizations should organize an internal labor market to attract, develop and retain talent. The purpose of this research is to study the impact of internal labour market and subjective career success perceived by engineers in organizations. For the study a survey was conducted via email to 1135 graduates with a response rate of $89.07 \%$.
\end{abstract}

\begin{abstract}
Structural equations were then applied to identify relationships. The results show a positive relationship between internal labour market and subjective career success perceived by engineers working in the organization. The conclusions of the study can help engineers and companies to drive the careers of these knowledge workers as a way to help them to be happier and help their companies to have more dynamic and proactive engineers. At the same time, educational institutions with engineering programs will gain a better understanding of an engineer's career, and will be able to use this knowledge to review the effectiveness of their educational programs.
\end{abstract}

Key words: Career success. Subjective career success. Internal labour market and career development for engineers.

1. Doutor em Gestão de Negócios pela ESADE, Espanha. Professor da Universidad ESAN, Escuela de Negocios, Peru. [abejarano@tecsup.edu.pe]

2. Doutora em Dirección de Empresas pela Universidad de Navarra - IESE, Espanha. Professora da Universidad ESAN, Escuela de Negocios, Peru. [kjauregui@esan.edu.pe]

Endereço dos autores: Alonso de Molina, 1652 - Monterrico, Surco, Lima - Peru 


\section{RESUMO}

Pelo fenômeno da crise global nos setores financeiro e de energia, e pelo surgimento de novas tecnologias, as empresas consideram que seu sucesso ou fracasso depende da capacidade de responder rapidamente às oportunidades em seu ambiente competitivo. Esta competitividade é encontrada principalmente na capacidade de seus profissionais técnicos. Por outro lado, a carreira é caracterizada como protéana, sem fronteiras e dirigida principalmente pelo indivíduo. Diante desse cenário, as organizaçóes devem organizar um mercado interno de trabalho para atrair, desenvolver e reter talentos. O objetivo desta pesquisa é estudar o incidência do mercado interno de trabalho e o sucesso profissional subjetivo percebido pelos engenheiros nas organizaçôes. Para o estudo foi realizada uma pesquisa via e-mail para 1.135 graduados com uma taxa de resposta de $89,07 \%$. Equações estruturais foram então aplicadas para identificar relacionamentos. Os resultados mostram uma relação positiva entre o mercado interno de trabalho e sucesso profissional subjetivo percebido por engenheiros que trabalham na organização. As conclusôes do estudo podem ajudar os engenheiros e as empresas a dirigir a carreira dos trabalhadores do conhecimento para que alcancem a felicidade e as empresas possam contar com engenheiros dinâmicos e proativos. Ao mesmo tempo, instituiçóes de ensino com programas de engenharia terão melhor compreensão da carreira de engenheiro, e poderão usar esse conhecimento para avaliar a eficácia de seus programas educativos

Palavras-chave: Sucesso na carreira. Sucesso subjetivo da carreira. Mercado interno de trabalho e progressão na carreira dos engenheiros.

\section{RESUMEN}

Ante el fenómeno de la crisis global, tanto en el sector financiero como en el energético y la irrupción de tecnologías emergentes, las empresas consideran que su éxito o fracaso depende de la capacidad de responder con agilidad a las oportunidades en su entorno competitivo. Esta capacidad competitiva radica especialmente en la capacidad de sus profesionales técnicos. Por otro lado, la carrera actual se caracteriza por ser proteica, sin fronteras y dirigida principalmente por el individuo. Ante este panorama las organizaciones deben organizar un mercado interno de trabajo capaz de atraer, desarrollar y retener talentos. Esta investigación tiene el propósito de estudiar la incidencia del mercado laboral interno y el éxito subjetivo de carrera percibido por los ingenieros en esta organización. Para el estudio se aplicó una encuesta, por correo electrónico, a 1135 graduados y el nivel de respuesta fue del $89.07 \%$. Luego se aplicaron ecuaciones estructurales para identificar las relaciones existentes. Los resultados muestran una relación positiva entre el mercado interno de trabajo y el éxito subjetivo de carrera percibido por los ingenieros que trabajan en la organización. Las conclusiones del estudio pueden ayudar a los ingenieros y a las empresas a conducir las carreras de los trabajadores del conocimiento de forma que alcancen la felicidad y las empresas puedan contar con ingenieros más dinámicos y proactivos. Igualmente los institutos de educación con programas de ingeniería pueden entender mejor cómo se desarrolla la carrera de un ingeniero y usar este conocimiento para reexaminar la efectividad de sus programas de formación.

Palabras clave: Éxito en la carrera. Éxito subjetivo de la carrera. Mercado interno de trabajo y desarrollo de la carrera de los ingenieros.

\section{INTRODUCTION}

Careers are of great interest to both the individual and the management of an organization. Career development has become a significant component of policy development in many countries, because of its potential impact on the labour market (RICHARD, 2005). The careers of engineers have been the subject of a series of studies that have in common the implicit assumption that the manufacturing of a country is dependent, at least in part, on the quality of 
its professional engineers (KEENAN, 1994). However, very promising engineers are being promoted to managerial positions as a way of recognizing their contribution to an organization's goals. But in doing so, the companies lose very knowledgeable professionals and, unfortunately, many of the engineers in question become poor managers (BARUCH, 1999).

Careers have become more open and more diverse, but also less structured and controlled by employers (BARUCH, 2003). Bartlett and Ghoshal (2002) hold that one of today's scarcest and most highly sought-after strategic resources is employee expertise. Being able to build competitive advantages through people and managing the careers of knowledgeable employees-like engineers - is a challenge for departments of Human Resources.

Technological and scientific advances are becoming available more quickly, and the company that misses the window of opportunity for taking advantage of these advances loses the pricing and profit premium available to market leaders. In many companies, science and technology has eclipsed marketing, finance, and even sales as the critical employee segment. These professionals can create the franchise for company growth. Managers of technical employees, like engineer, have a lot to consider as they attempt to limit the turnover of valuable employees. Career opportunities yielded significant predictors of retention than any other type of reward for technical professionals (KOCHANSKI; LEDFORD, 2001). In the face of global competition for engineering talent, Human Resource Managers need to pay more attention to the internal labour market of the company.

The key role of engineers in company performance has been emphasized in several studies. Engineers, in fact, represent a distinct occupational group: engineering does not quite fit the classic definition of a profession like medicine or law; but there are many elements of professionalism in engineering. Engineers, however, have a stronger need for personal development and growth compared to professionals in other occupations. They need to learn new things, and to feel challenged. As a result of changes in economic, social, and technological conditions, engineering managers today face more problems in retaining engineers than ever before. This fact, in addition to engineers' orientations and expectations to be treated as professionals, has caused considerable tension and strain in the engineer-management relationship. This calls for changes in engineering management styles to maintain motivation and productivity (BLIGLIARDI; PETRONI; DORMIO, 2005; KEENAN, 1994).

Engineers develop their careers inside the organisations that offer positions in their areas of research and development, logistics, communications, information systems, production, maintenance, and sales, among others. The internal labour market have the potential to become a factor of career success of engineer. This research analyzes the internal labour market as factor of career success perceived by engineers.

The design of the present research was guided by one central question: What is the relationship between technologists' career success and the internal labour market in the organizational?

This cross-sectional survey study employed a questionnaire in order to examine the internal labour markets as factor of career success perceived by engineers. Both objective and subjective perspectives were used, developing empirical evidence for career success of this category of knowledge workers in Latin America.

A better understanding of engineers' career success determinants can help both organizations to be better companies and individuals to achieve their specific goals. Latin American and Western academic journals have contained few papers that discussed career of Latin American engineers

\section{LITERATURE REVIEW}

\section{I Career}

From a sociological perspective, a career is defined with a structural term as a succession of related jobs, arranged in hierarchy of prestige, 
through which persons move in an ordered (more or less predictable) sequence (GARAVAN; COOLAHAN, 1996). In a more psychologically oriented definition, career is the sequence of a person's work-related activities, behaviours, and associated attitudes, values, and aspirations over the span of one's life (ADAMSON, 1997; GARAVAN; COOLAHAN, 1996; HALL, 1986). A career can be viewed fundamentally as a "vehicle" for the continuous realization of self, or more accurately, as a vehicle by means of which an individual may begin to construct a clearer conception of self and self in the world (ADAMSON, 1997).

In this way, the concept of career has a different set of associations when viewed as a sequence of promotions and other upward moves than when it is viewed as a lifelong sequence of jobs or of role-related experiences (HALL, 2002). One widely accepted definition of career is the unfolding sequence of a person's work experiences over time. This definition insists on the relevance of time, rather than adopting a static view of work arrangements (ARTHUR; KHAPOVA; WILDEROM, 2005).

The concept of career changes from the traditional linear model of career as a sequence of hierarchical promotions with a clear unidimensional or linear direction of prescribed "advancement" within the organizational hierarchy, to modern, non-traditional models that pay attention to the changing world of career that include alternative career paths as the careers of individuals who may opt-out of corporations in order to start their own businesses (BARUCH, 2004; SULLIVAN et al., 2007).

The most important concepts occurring in studies of the state of today's career realities are:

a) the "boundaryless" career introduced by Defillipi and Arthur (1994) (short-termism and involves a new form of employability in which the individual, rather than the organization, takes an active rather than passive role in managing his or her career);

b) the "protean" career presented by Hall (1996), an individual-focused approach, in which it is claimed that individuals are responsible for their careers and that their unique human resource qualities are based on continuous learning and growth in the pursuit of career goals. The protean model assumes that careers continue to develop throughout life as skills and knowledge are continuously sought in accordance to individual goals;

c) the "intelligent" career proposed by Defillipi and Arthur (1994), which speaks of the development of three "ways of knowing": knowing-why, knowing-how, and knowingwhom, which are primarily individual assets of motivation, skills, and relationships;

d) the "post-corporate" career presented by Peiperl and Baruch (1997). On their view, career paths are horizontally rather than vertically evolving links that transcend geographical and organizational boundaries);

e) the "multidirectional" career by Baruch (2004);

f) the "customized" career presented by Valcour, Bailyn and Quijada (2007); and

g) the "kaleidoscope" career model of Mainiero and Sullivan (2005), according to which careers are created on the individual's own terms, and are not defined by the corporation, but by the individual's personal values and life choices. Like a kaleidoscope, individuals' careers are dynamic and in motion. As their lives change, they can alter their career paths to adjust to these changes and need not rely on corporate dictates (HASSAN, 2007; MCDERMID et al., 2001; SULLIVAN et al., 2007).

Also important are the internal and external perspectives presented by Van Maanen and Schein (1975). The external career refers to the more or less objective categories used by members of society to describe the progression of steps through a given occupation. The internal career refers to the set of steps that make up the individual's own concept of his progress within an occupation. Career development is a function of individual and organizational dimentions of career. 
According to these two perspectives, careers can also be described in two fundamentally different ways. On the one hand, there are subjective careers, reflecting the individual's own sense of his or her career and the direction in which it is heading. On the other hand, there are objective careers, which reflect the more or less publicly observable positions, situations, and status "that serve as landmarks for gauging a person's movement through the social milieu" (BARLEY, 1989 apud ARTHUR; KHAPOVA; WILDEROM, 2005, p. 179).

It is not only the individual who needs to pay attention to career transitions. Organizations should not merely look at past, static, narrow concepts of careers, but should enlarge the concept to encompass new, more change-oriented careers. This repeated cycle of "out with the old, in with the new" is likely to increase rather than reduce pandemonium. Rather, a more powerful strategy is to incorporate older, more static career concepts along with newer, more dynamic career concepts into a pluralistic strategy for dealing with careers and organizational arrangements. A pluralistic framework will serve as a means for coping with change and the diverse needs of organizations and people, and at the same time as a tool for realigning individuals and organizations (BROUSSEAU et al., 1996).

\subsection{Subjetive career success}

Career success is an outcome of a person's career experiences. Career success may be defined as the accomplishment of desirable work-related outcomes at any point in a person's work experiences over time. This encompasses the definition of career provided above. It also encompasses two meanings of success given by the Oxford English Dictionary (1989 apud ARTHUR; KHAPOVA; WILDEROM, 2005): "the attainment of an object according to one's desire," and "the prosperous achievement of something attempted". The first meaning suggests a form of success that is personally (i.e., subjectively) desirable, while the second suggests a form of success - prosperity - that is likely to rely on (largely objective) social comparisons. These alternative meanings suggest that, as with careers, there are two distinct ways of viewing career success (ARTHUR; KHAPOVA; WILDEROM, 2005).

The concept of career success has followed the evolution of the concept of career from traditional definitions of career success as climbing up the corporate ladder and seeking such extrinsic rewards as salary and bonuses, to more recent definitions of career success, which typically include objective, extrinsic measures as well as subjective assessments, including the individual's attitudes about his or her career. The concept of success changes throughout the work lives of professionals. Young professionals perceive career success especially as an individualistic and multidimensional concept (MCDONALD, 2008; SULLIVAN et al., 2007).

Intrinsic outcomes of career success (i.e., subjective career success) depend on a person's own appraisal of his or her success. Subjective career success refers to a person's own internal perspective on his or her success (POON, 2004). The idea of the protean career, managed by the person not the organization, is strongly advocated by Hall and Moss (1998), the criteria for success here being internal not external (ATKINSON, 2002).

Subjective career success is theoretically more complex. It refers to an employee's evaluations of his or her own career success with reference to self-defined standards, career stage, aspirations, and the opinions of significant others. Subjective career success is a broad, multidimensional construct. It incorporates perceptions of intrinsic success (e.g. work-role, interpersonal success) and extrinsic success (financial, hierarchical success) with respect to achievements, aspirations, and colleagues in the present organizations (NABI, 2001).

\subsection{Internal labour market}

The internal labour market is often used as a process to create an internal mobility in an organisation. The opportunities to cover new posts created in an organisation are in function of specific 
qualifications exigency, rules for promotion or employees transfer. The internal labour market is composed of the organisational structure and organisation policies (e. g. rules set and proceedings for promotions, wage fixation, and work assignment). The internal labour market determines mobility and development opportunities and other career characteristics employees may have (GARAVAN; COOLAHAN, 1996).

The internal labour market size is positively related to the opportunities received by the employees for the development of their careers and training. Organisations divide the career into two important parts: firstly, the functions division of jobs in the organisations generate the distribution of opportunities and prizes commonly fixed before hiring personnel; secondly, the organisational proceedings to assign the personnel to jobs affect the distribution of prizes and opportunities in the enterprise and so, influence on the probability to have a career success (PFEFFER; COHEN, 1984).

The academicians (NABI, 1999; PFEFFER; COHEN, 1984) who study the organisations propose that the career success perceived is influenced by the existence of an internal labour market. The career plans are referred to the structured ladder of work progression entering at the low level of the hierarchy and promotion associated to the development of skills and experience.

Nabi (1999) suggests that the presence of a well-structured internal labour market positively influences on the opportunity of a career success in terms of promotion in the hierarchy and improvement of their compensations. These compensations may be economic or emotional. The lack of possibilities of a career development inside the organisations may be a cause for the high turnover rate of the collaborators.

The career development plans performed by the organisations with jobs related to the engineering profession must take into account the great necessity of growing and personal development demanded by engineers compared to other professionals, as well as the great necessity to keep themselves updated and a strong wish of facing challenges. For that reason, engineers are searching jobs that fulfil their necessities (LEE, 2002).

According to this literature, the following conceptual frame is proposed:

\section{METHODOLOGY}

The present research is a cross-sectional and explicative quantitative study The strategy of inquiry selected was the quantitative approach. It is often employed when the study is oriented to testing theory and understanding the best predictors of outcomes (CRESWELL, 2003; TASHAKKORI; TEDDLIE, 1998).

The specific method of data collection in this cross-sectional study was a questionnaire with statistical analysis, with the intent of generalizing from a sample to a population that does not require control of behavioural events and focuses on contemporary events (YIN, 2003). Aiming to obtain 1000 answers, a stratified sample was defined with 1135 graduates of Peruvian

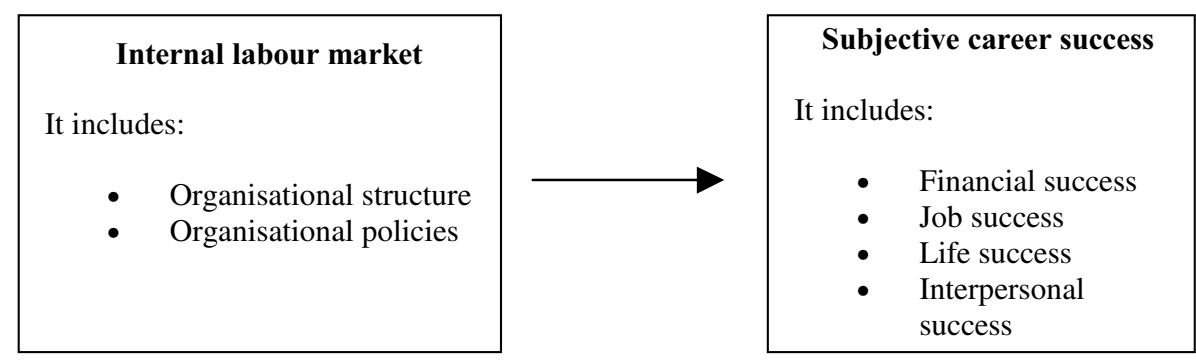

Figure 1 - Relation between the internal labour market and the subjective career success.

Source: Own elaboration based on Arthur, Khapova, Wilderom (2005); Pfeffer, Cohen (1984); Daft, Lewin (2008); Garavan, Coolahan (1996); Lee (2002) and Nabi (1999). 
technological institution. From the relation of the total population of 3407 graduates sorted by years of experience (arranged in a descending order from bigger than minor professional experience) and with jump of 3, 1135 graduates were selected. After the piloting (pre-testing) phase, the final survey was sent on January 2, 2008, and the total number of answers received as of February 29, 2008 was 1011 . The response rate was $89.07 \%$, extremely high. In this study, the unit of analysis considered is the individual graduated from an engineering technology program.

\section{I Survey design}

The development of instruments for all dimensions in this study was carried out in three stages according the procedure proposed by Boon-Itt and Paul (2006). First, in the design stage, scales for each variable used in previous research were selected through a literature review. The initial set of scales was translated into Spanish with a special attention to question phrasing in order to create a reliable instrument and with this purpose it was pre-tested with graduates and practitioners in order to provide confirmatory reliability.

The second stage includes survey development through a pilot test using a small sample of the target population for assessing the validity and reliability of the translated survey. In this stage, each item was tested in relation to how it works with each construct. Finally, in the third stage, survey evaluation was developed with the final version of the survey and it was applied to the final sample. The validity and reliability assessment measures were probed again. The survey was designed with special attention to the relevance of the research questions and the goal of the study (BAILEY, 1994; SCHWARTZ, 1978).

\subsection{Measurement}

The operationalization in this study was made according the following criteria: the experience of the researcher, variables which the researcher believe he can measures, the focus of the study, costs and time.

\subsection{Subjective career success}

This was assessed with the five-point scale used by Gattiker and Coe (1986) to define four factors of perception of career success: (1) Job Success (Initially with 18 items and alpha $=0.94$ in the pilot phase and finally with 16 items and alpha $=$ $0.93)$, which reflects individual perceptions about job satisfaction; (2) Life Success (Initially with 8 items and alpha $=0.81$ in pilot phase and finally with 4 items and alpha $=0.81$ ), which reflects individual perceptions about satisfaction with life overall; (3) Financial Success (Initially with 6 items and alpha $=0.86$ in pilot phase and finally with 3 items and alpha $=0.86$ ), which reflects individual perceptions of compensation, and (4) Interpersonal Success (Initially with 6 items and alpha $=0.72$ in the pilot phase and finally with 4 items and alpha $=0.69$ ), which reflects individual perceptions about satisfaction about the relationship with peers.

The table 1 shows the main components and item-total scale analysis used to measure the subjective career success. The respondents were requested to check a box from (1) "Agree completely" to (5) "Disagree completely" to indicate their level of agreement with such statements as "I am receiving positive feedback about my performance from all peers" (job success); "I am happy with my private life" (life success); "I am receiving fair compensation compared to my peers" (financial success); "I am often asked for advice on private matters by my peers" (interpersonal success).

\subsubsection{Internal labor market}

After a detailed review of literature the questionnaire of Nabi (2001) was selected due the use of items measuring internal labour market both in dimension of structure and practices. Respondents were required to assess the extent to which each item described their organizations career related practices on a five point scale 
Table 1 - Main components and item-total scale analysis used to measure the subjective career success.

\begin{tabular}{|c|c|c|c|c|c|c|c|}
\hline \multirow[t]{3}{*}{ Item } & \multicolumn{4}{|c|}{ Rotated component matrix(a) } & \multirow{2}{*}{\multicolumn{2}{|c|}{ Item - Total Statistics }} & \multirow{2}{*}{$\begin{array}{c}\text { Reliability } \\
\text { statistics } \\
\text { Cronbach's } \\
\text { Alpha } \\
\end{array}$} \\
\hline & \multirow{2}{*}{$\begin{array}{c}\text { Component } \\
1\end{array}$} & \multirow[b]{2}{*}{2} & \multirow[b]{2}{*}{3} & \multirow[b]{2}{*}{4} & & & \\
\hline & & & & & $\begin{array}{l}\text { Corrected Item - } \\
\text { Total Correlation }\end{array}$ & $\begin{array}{l}\text { Cronbach's Alpha } \\
\text { if Item Deleted }\end{array}$ & \\
\hline $\mathrm{P} 1$ & 0.523735520 & & & & 0.500545429 & 0.931487640 & 0.932204299 \\
\hline $\mathrm{P} 2$ & 0.582336808 & & & & 0.543710880 & 0.930606804 & \\
\hline P3 & 0.679028469 & & & & 0.657810660 & 0.927936507 & \\
\hline $\mathrm{P} 4$ & 0.639269309 & & & & 0.597345727 & 0.929415030 & \\
\hline P5 & 0.759829219 & & & & 0.726995661 & 0.926069678 & \\
\hline P6 & 0.687037665 & & & & 0.661839233 & 0.927844220 & \\
\hline $\mathrm{P} 7$ & 0.712382938 & & & & 0.664785525 & 0.927756433 & \\
\hline P8 & 0.719433022 & & & & 0.699190778 & 0.926857413 & \\
\hline P9 & 0.726928727 & & & & 0.664177348 & 0.927779551 & \\
\hline $\mathrm{P} 10$ & 0.754782638 & & & & 0.699378923 & 0.926836868 & \\
\hline P11 & 0.719055380 & & & & 0.645577744 & 0.928248258 & \\
\hline $\mathrm{P} 12$ & 0.768059595 & & & & 0.699620013 & 0.926831262 & \\
\hline $\mathrm{P} 13$ & 0.751522230 & & & & 0.685655789 & 0.927213508 & \\
\hline P14 & 0.808661842 & & & & 0.742994744 & 0.925616265 & \\
\hline $\mathrm{P} 15$ & 0.596517092 & & & & 0.554880779 & 0.930370034 & \\
\hline P16 & 0.735287870 & & & & 0.704447032 & 0.926698455 & \\
\hline P17 & & & 0.741494082 & & 0.586756783 & 0.779998977 & 0.809721702 \\
\hline P18 & & & 0.684087409 & & 0.701980292 & 0.723890456 & \\
\hline P19 & & & 0.667208252 & & 0.692097051 & 0.729346814 & \\
\hline $\mathrm{P} 20$ & & & 0.729894252 & & 0.55312387 & 0.796859165 & \\
\hline $\mathrm{P} 21$ & & 0.56838586 & & & 0.681274845 & 0.871363866 & 0.886383935 \\
\hline $\mathrm{P} 22$ & & 0.57776991 & & & 0.653096832 & 0.874184388 & \\
\hline $\mathrm{P} 23$ & & 0.74000203 & & & 0.791090025 & 0.851025693 & \\
\hline $\mathrm{P} 24$ & & 0.71578435 & & & 0.701781323 & 0.866779220 & \\
\hline $\mathrm{P} 25$ & & 0.75124896 & & & 0.737581857 & 0.861077559 & \\
\hline $\mathrm{P} 26$ & & 0.67958686 & & & 0.651533734 & 0.874337308 & \\
\hline $\mathrm{P} 27$ & & & & 0.542578384 & 0.383950637 & 0.672234405 & 0.685829673 \\
\hline $\mathrm{P} 28$ & & & & 0.758831893 & 0.549902911 & 0.580571917 & \\
\hline P29 & & & & 0.709657268 & 0.554298603 & 0.560780911 & \\
\hline \multirow[t]{2}{*}{$\mathrm{P} 30$} & & & & 0.541007384 & 0.412363732 & 0.656438639 & \\
\hline & \multicolumn{3}{|c|}{ Rotation converged in 6 iterations. } & & & & \\
\hline
\end{tabular}

(completely disagree $=1$ to completely agree $=5$ ). The original instrument was tested and after the semantic adaptation of redaction of each items a contextual and reviewed version were used in this study for measuring organizational activities, reward distribution, career progression practices as the perception of a well structured career ladder.
The method of the principal components was applied to check the validity of the scale of Internal Labour Market which composed by 4 items and not applied to the independent variables. This method was used in our study to verify the validity of the scale, if the items are organized under the definition of the construct 
Table 2 - Analysis of the main components and item-total scale used for the structure of the internal labour market.

\begin{tabular}{c|c|c|c|c}
\hline \multicolumn{5}{c|}{ Component Matrix(a) } \\
\hline Component & \multicolumn{1}{|c|}{ Item - Total Statistics } & $\begin{array}{c}\text { Corrected Item - } \\
\text { Total Correlation }\end{array}$ & $\begin{array}{c}\text { Cronbach's Alpha if } \\
\text { Item Deleted }\end{array}$ & $\begin{array}{c}\text { Cronbach's } \\
\text { Alpha }\end{array}$ \\
\hline 1 & Item & 0.738838192 & 0.887005123 & \\
\hline 0.85116989 & There is a clearly defined structure & 0.815511917 & 0.859258528 & \multirow{2}{*}{0.90141954} \\
\hline 0.90158303 & There is a related career progression & 0.768105086 & 0.876736886 & \\
\hline 0.87121393 & Work levels at the entrance & 0.795758895 & 0.866670271 & \\
\hline
\end{tabular}

1 component extracted.

to be measured. In order that a correct application of factorial analysis, two basic conditions were considered: parsimony (defined with the lowest number of possible items) and interpretability (factor needs capacity of substantive interpretation). The table 2 shows the results of the main components and item-total scale analysis performed to measure the internal labour market in an organisation.

A descriptive statistics and inferential statistics was obtained with the SPSS 15.0. Among the three approaches usually associated with SEM (strictly confirmatory, alternative models, and model development), this study uses the confirmatory approach; in this way, the model generated by theory was tested using SEM procedures to determine if the pattern of data was consistent with the theoretical model.

A further advantage of examining variables within an SEM framework is the ease with which problems in the data, such as abnormal or missing data, can be handled using special and/or robust estimators that can be implemented in most SEM packages. Depending on the software package, estimation methods have been developed recently that are capable of addressing both abnormal and missing data (BRYAN; SCHMIEGE; BROADDUS, 2007). This study uses AMOS, the SPSS version of SEM.

\section{RESULTS}

Although the theoretical condition of the normal distribution assumption is still not present in the study, the influence of non-normal data is reduced when using an SEM with a larger sample size. A sample size is considered large when the ratio between the sample size and the number of observed variables is not less than 15 (STEVENS, 1996). In this study the sample is considered to be large since the ratio is $>15$, more than the recommended threshold (CAO; MOKHTARIAN; HANDY, 2007).

$\mathrm{Hu}$, Bentler and Kano (1992) analyzed the performance of estimation procedures with different sample sizes and violations of the hypotheses of normality. These authors recommend the method of generalized least squares (GLS) under considerations of less rigorous multivaried normality as the case of this study. The GLS was used to improve the estimation of parameter (KUAN, [2004]) and to compute parameter estimates, correctness of fit tests, and standard errors.

The results of our analysis support the hypothesis that internal labor market is positively related to career success perceived by an engineer with a highly significant significant relationship $(\beta=0.63$ and $p<0.001)$. 
The next step was to assess the overall model and check to see if the model fits the empirical data. Overall fit of SEM models can be determined by a multitude of fit indexes, each with its associated advantages and disadvantages. $\mathrm{Hu}$ and Bentler provide an overview of available indexes, as well as guidelines for assessing the acceptable range for each index (BRYAN; SCHMIEGE; BROADDUS, 2007).

Initially CMIN/DF was used. CMIN/DF is the minimum sample discrepancy divided by degrees of freedom. This is called the relative chisquare or normal chi-square. Some researchers allow values as large as 5 for adequate fits, but more conservative researchers reject models with a relative chi-square greater than 2 or 3 (GARSON, c1998).

Given the fact that chi-square statistics and the CMIN/DF (chi-square divided by the degrees of freedom) are affected by sample size, and are very unlikely to meet accepted levels, the Goodness of Fit Index (GFI), the Adjusted Goodness of Fit Index (AGFI), and the Parsimonious Goodness of Fit Index (PGFI) were also used to assess the model's fit. The figure 2 shows the pattern with the resulting values of the structural equations application.

GFI is the Goodness of Fit Index. GFI varies from 0 to 1 . By convention, GFI should be equal to or greater than 0.90 if the model is to be accepted. AGFI is the Adjusted Goodness of Fit Index. AGFI is a variant of GFI and varies from 0 to 1 . AGFI should also be at least 0.90. PGFI should be equal to or greater than 0.05 .

To evaluate the data adjustment of the data pattern, four index of adjustment measurement was obtained from AMOS:

a) CMIN/DF (Chi Square Minimum Sample Discrepancy): according to the most conservative researchers it must be between 2 to 3 to show a good adjustment although values near 5 (GARSON, c1998) are accepted;

b) GFI (Goodness of Fit Index);

c) AGFI (Adjusted Goodness of Fit Index), and;

d) RMSEA (Root Mean Square Error of Approximation). GFI and AGFI indexes must be over 0.90 as it is recommended; RMSEA must be under 0.06 .

The table 3 shows the obtained values.

Table 3 -Adjustment summary of the used pattern. CMIN/DF, GFI, AGFI and RMSEA are adjustment indexs.

\begin{tabular}{c|c}
\hline Adjustment measurement & Value \\
\hline CMIN/DF & 3.338 \\
\hline GFI & 0.899 \\
\hline AGFI & 0.884 \\
\hline RMSEA & 0.048 \\
\hline
\end{tabular}

\section{DISCUSSION AND CONCLUSIONS}

This study reveals characteristics on career development of Peruvian engineers with orientation to the practice and further insight into the career success perceived by engineer was sought. Overall, an internal labor market was found as very important factor of career success perceived in careers of engineers. The results support the hypothesized relationship between organizational structure and career success with empirical data. The organizational labor market allocates labor, determines wages, and defines the scope of specific jobs according to sets of rules and procedures (O'MAHONY; BECHKY, 2006).

The need to improve the measurement of subjective career success has been demonstrated in several studies (ARTHUR; KHAPOVA; WILDEROM, 2005, GUNZ; HESLIN, 2005; HESLIN, 2005). In the present study, the questionnaire has self-referent items (evaluation of career success relative to personal standards and preferences) as well as other-referring items (evaluation of career success relative to the outcomes achieved by other people). Items related to job success explain a significant amount of total variance in subjective career success and SEM shows high value of beta (0.94) between job success and subjective career success. One possible explanation of this finding has to do with the Latin American context, in which jobs are people's 
foremost concern. In Peru 60\% of the population is unemployed or underemployed and some of the first effects of the financial world crisis is a strong reduction of the growth of the employment.

The importance and prominence of organizational career planning and management as part of Human Resources management has been recognized by many scholars (BARUCH, 2003; HALL, 1986; HASSAN, 2007; VAN MAANEN; SCHEIN, 1975). The positive relationships found among internal labor market with career success perceived is consistent with these past researches. Part of the explanation may be the fact that careers of engineers mostly take place within an organization. In this study, the percentage of engineers employed as dependent worker was $94 \%$, as against only $6 \%$ independent workers.

Moving into higher positions in the career of engineers is associated with positions as senior

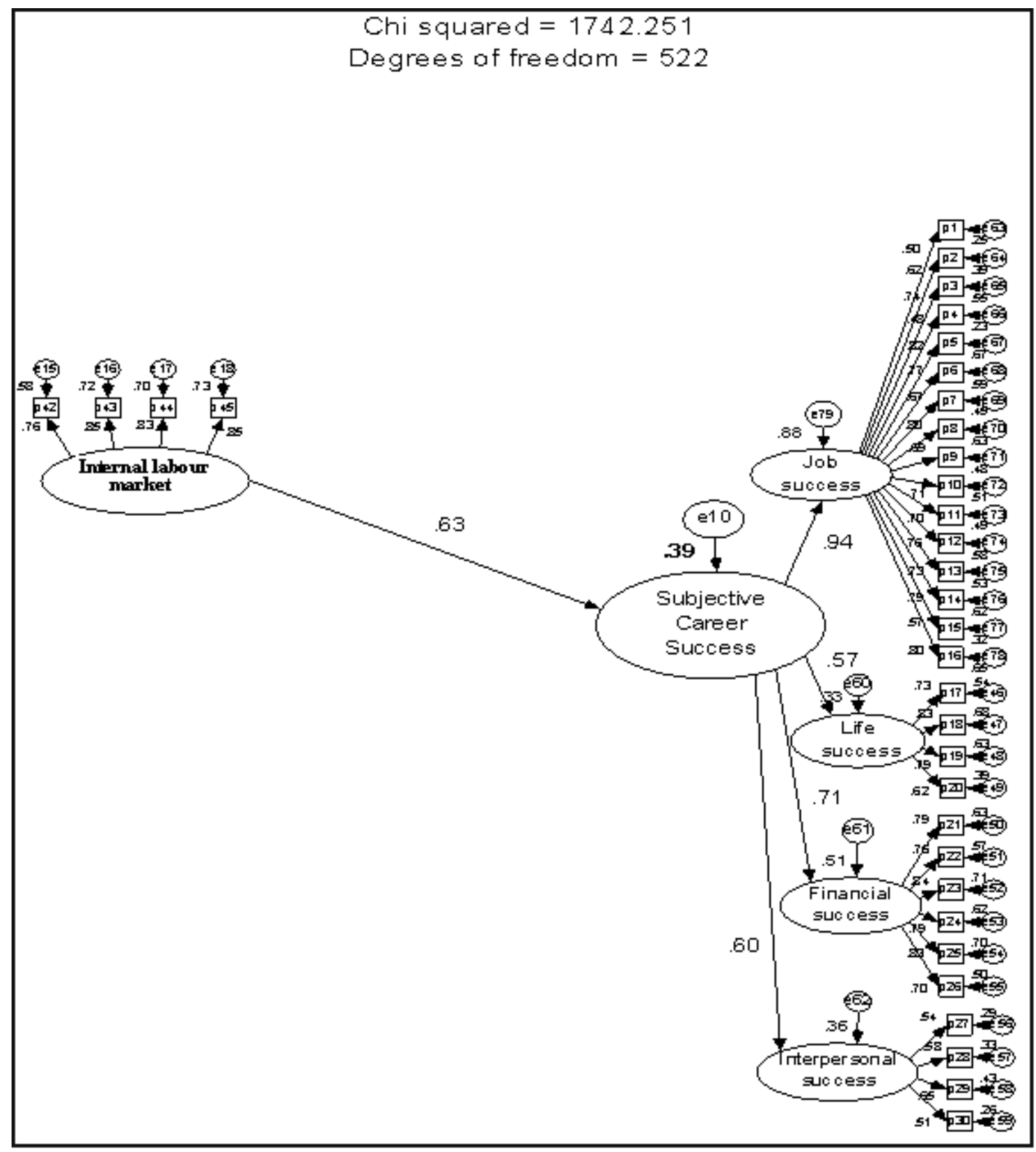

Figure 2 - Structural Equations Pattern. 
engineer or, at least, expert coordinator. These positions need a specific set of skills for effective performance and career success (MAINIERO, 1986). Engineers are very active in continuos educations activies and they have the expectations of promotions in the internal labor market.

Organizations can use the results of this study to design internal labor markets, internal career structures, and specific programs aimed at enhancing the career success of employees. Despite the fact that the literature on career has focused on the individual, it is necessary for the organization to have an effective management of the careers of their knowledge workers, so as not to lose this competitive value. Strategic human resource scholars have argued that companies can effectively influence the interactions, behaviors, and motivation of employees through different human resource practices (COLLINS; SMITH, 2006).

Organizations must attend to the proportion of the technical staff that prefers to remain in full contact with technical problem solving, for which management has no attraction. The traditional technical ladder of promotion then becomes a consolation prize, and very often de-motivates an otherwise productive member of the technical staff (MAINIERO, 1986; PETRONI, 2000).

\section{REFERENCES}

ADAMSON, S. J. Career as vehicle for the realization of self. Career Development International, Bradford, v. 2, n. 5, p. 245-253, 1997.

ARTHUR, M. B.; KHAPOVA, S. N.; WILDEROM, C. Career success in a boundaryless career world. Journal of Organizational Behavior, Hoboken, v. 26, n. 2, p. 177-202, Mar. 2005.

ATKINSON, C. Career management and the changing psychological contract. Career Development International, Bradford, v. 7, n. 1, p. $14-23,2002$.

BARTLETT, C.; GHOSHAL, S. Building competitive advantage through people. MIT
Sloan Management Review, Boston, v. 43, n. 2, p. 34-41, Winter 2002.

BARUCH, Y. Integrated career system for the 2000s. International Journal of Manpower, Bradford, v. 20, n. 7, p. 432-457, July 1999.

Career systems in transition. Personnel Review, Bradford, v. 32, n. 2, p. 231-251, Apr. 2003.

.Transforming careers: from linear to multidirectional career paths: organizational and individual perspectives. Career Development International, Bradford, v. 9 ,n. 1, p. 58-73, 2004.

BAILEY, K. Methods of social research. New York: Free Press, 1994.

BLIGLIARDI, B.; PETRONI, A.; DORMIO, A. Organizational socialization, career aspirations, and turnover intentions among design engineers. Leadership \& Organization Development Journal, Bingley, v. 26, n. 6, p. 424-441, Feb. 2005.

BOON-ITT, S.; PAUL, H. Study of supply chain integration in Thai automotive industry: a theoretical framework and measurement. Management Research News, Bingley, v. 16, n. 1, p. 101-116, jan. 2006.

BROUSSEAU, K. et al. Career pandemonium: realigning organizations and individuals. Academy of management executives, Biarcliff Manor, v. 10, n. 4, p. 52-66, Nov. 1996.

BRYAN, A.; SCHMIEGE, S.; BROADDUS, M. Mediational analysis in HIV/AIDS research: estimation multivariate path analytic models in a structural equations modeling framework. AIDS Behavior, New York, v. 11, n. 3, p. 365-383, 2007.

CAO, X.; MOKHTARIAN, P.; HANDY, S. Do changes in neighborhood characteristic lead to changes in travel behavior? a structural equations modeling approach. Transportation, Dordrecht, v. 34, n. 5, p. 535-556, Sept. 2007. 
COLLINS, C.; SMITH, K. Knowledge exchange and combination: the role of human resource practices in the performance of high-technology firms. Academy of Management Journal, Biarcliff Manor, v. 49, n. 3, p. 544-560, 2006.

CRESWELL, J. Research design: qualitative, quantitative, and mixed method approaches. Thousand Oaks: Sage Publications, 2003.

DAFT , R.; LEWIN, A. Rigor and relevance in organizational studies. Organization Science, Linthicum,v. 19,n. 1, p. 177-183, 2008.

DEFILLIPI, R.; ARTHUR, M. The boundaryless career: a competency based perspective. Journal of Organizational Behavior, Binghanton, v. 15, n. 4, p. 307-324, 1994.

GARAVAN, T.; COOLAHAN, M. Career mobility in organizations: implications for career development: part I. Journal of European Industrial Training, Bradford, v. 20, n. 4, p. 30-40, Apr. 1996.

GARSON, G. D. Structural equation modeling. Raleigh: North Carolina State: University, c1998. Disponível em: <http://faculty.chass.ncsu.edu/garson /PA765/structur.htm>. Acesso em: 23 maio 2008.

GATTIKER, U.; COE, L. Relationship of computer attitudes with perception of career success. In: ANNUAL MEETING OF THE ACADEMY OF MANAGEMENT JOURNAL, 46., 1986, New York. Best papers proceedings... Biarcliff Manor: Academy of Management, 1986. p. 294-298.

GUNZ, H.; HESLIN, P. Reconceptualizing career success. Journal of Organizational Behavior, Chichester, v. 26, n. 2, p. 105-11, 2005.

HALL, D. Career development in organizations. San Francisco: Jossey-Bass, 1986.

Careers in and out of organizations.

Thousand Oaks: Sage, 2002.
Protean careers of the 21 st century. Academy of Management Executives, Biarcliff Manor, v. 10, n. 4, p. 8 -16, 1996.

; MOSS, J. The new protean career contract: helping organizations and employees. Organizational dynamics, New York, v. 6, n. 3, p. 22-37, 1998.

HASSAN, B. Career success, the effects of human capital, person-environment fit and organizational support. Journal of managerial psychology, Bradford, v. 22, n. 8, p. 741-765, 2007.

HESLIN, P. Conceptualizing and evaluating career success. Journal of organizational behavior, Chichester, v. 26, n. 2, p. 113-136, 2005.

HU, L. T.; BENTLER, P.; KANO, Y. Can test statistics in covariance structure analysis be trusted? Psychological Bulletin, Washington, D. C., v. 112, n. 2, p. 351-362, 1992.

KEENAN, T. Undergraduate education and the career orientation of professional engineers: comparison between individuals from enhanced engineering courses and those from conventional engineering courses. Journal of Occupational and Organizational Psychology, Biggleswade, v. 67, n. 2, p. 153-172, June 1994.

KOCHANSKI, J.; LEDFORD, G. How to keep me: retaining technical professionals. IEEE Engineering Management Review, Piscataway, v. 29, n. 4, p. 69-75, 2001.

KUAN, C M. Introduction to econometric theory. Taipei: Institute of Economics, Academia Sinica, [2004]. Disponível em: <http:// www.sinica.edu.tw/as/ssrc/ckuan/pdf/et01/>. Acesso em: 03 jul. 2007.

LEE, P. Career goals and career management strategy among information technology professionals. Career Development International, Bradford, v. 7, n. 1, p. 6-13, 2002. 
MAINIERO, L. Early factors that differentiate technical management careers from technical professionals careers. Journal of Management, Thousand Oaks, v. 12, n. 4, p. 561-575, Dec. 1986.

MAINIERO, L.; SULLIVAN, S. Kaleidoscope careers: an alyternate explanation for the "optout" revolution. Academy of Management Executive, Biarcliff Manor, v. 19, n. 1, p. 106123, 2005.

MCDERMID, S. et al. Alternative work arrangements among professionals and managers: rethinking career development and career success. The Journal of Management Development, Bradford, v. 20, n. 4, p. 305-317, 2001.

MCDONALD, K. The next generation of career success: Implications for HRD. Advances in Developing Human Resources, Thousand Oaks, v. 10, n. 1, p. $86-110,2008$.

NABI, G. An investigation into the differential profile of predictors of objective and subjective career success. Career Development International, Bradford , v. 4, n. 4, p. 212-224, 1999.

. The relationship between HRM, social support, and subjective career success among men and women. International Journal of Manpower, Bradfordv. 22, n. 5, p. 454-474, 2001.

O'MAHONY, S.; BECHKY, B. Stretwork: managing the career progression paradox in external labor market. Academy of Management Journal, Biarcliff Manor, v. 49, n. 5, p. 918-941, 2006.

PEIPERL, M.; BARUCH, Y. Back to square zero: the post-corporate career. Organizational Dynamics, New York, v. 25, n. 4, p. 7-22, 1997.

PFEFFER, J.; COHEN, Y. Determinants of internal labor markets in organizations. Administrative Science Quarterly, Ithaca, v. 29, n. 4, p. 550-572, Dec. 1984.
PETRONI, A. Strategic career development for R \& D staff: a field research. Team Performance Management, Bradford, v. 6, n. 3, p. 52-61, 2000.

POON, J. Career commitment and career success: moderating role of emotion perception. Career Development International, Bradford, v. 9, n. 4, p. 374-390, 2004.

RICHARD, G. International best practice in career development: review of literature. International Journal for Educational and Vocational Guidance, Dordrecht, n. 5, n. 2, p. 189-201, 2005.

SCHWARTZ, G. Estimating the dimension of a model. Annals of Statistics, Hayward, v. 6, n. 2, p. 461-464, 1978.

STEVENS, J. Applied multivariate statistics for the social sciences. New Jersey: Lawrence Erlbaum Associates, 1996.

SULLIVAN, S. et al. What motivates entrepreneurs? an exploratory study of the kaleidoscope career model and entrepreneurship. Journal of Applied Management and Entrepreneurship, Fort Laudedale-Davie, v. 2, n. 4, p. 4-119, 2007.

TASHAKKORI, A.; TEDDLIE, H. Mixed methodology. London: Sage, 1998.

VALCOUR, M.; BAILYN, L.; QUIJADA, M. Customised careers. In:GUNZ, H.; PEIPERL, M. (Ed.). Handbook of career studies. London: Sage, 2007. p. 188-210.

VAN MAANEN, J.; SCHEIN, E. Improving the quality of work life: career development. Cambridge, MA: Massachusetts Institute of Technology Press, 1975.

YIN, R. Case study: research, design and methods. London: Sage, 2003. 